\title{
Oxygen consumption is depressed in patients with lactic acidosis due to biguanide intoxication
}

\author{
Alessandro Protti*1 ${ }^{*}$, Riccarda Russo ${ }^{1}$, Paola Tagliabue², Sarah Vecchio ${ }^{3}$, Mervyn Singer ${ }^{4}$, Alain Rudiger ${ }^{5}$, Giuseppe Foti², \\ Anna Rossi6, Giovanni Mistraletti and Luciano Gattinoni ${ }^{1}$
}

\begin{abstract}
Introduction: Lactic acidosis can develop during biguanide (metformin and phenformin) intoxication, possibly as a consequence of mitochondrial dysfunction. To verify this hypothesis, we investigated whether body oxygen consumption $\left(\mathrm{VO}_{2}\right)$, that primarily depends on mitochondrial respiration, is depressed in patients with biguanide intoxication.

Methods: Multicentre retrospective analysis of data collected from 24 patients with lactic acidosis $(\mathrm{pH} 6.93 \pm 0.20$; lactate $18 \pm 6 \mathrm{mM}$ at hospital admission) due to metformin $(n=23)$ or phenformin $(n=1)$ intoxication. In 11 patients, $\mathrm{VO}_{2}$ was computed as the product of simultaneously recorded arterio-venous difference in $\mathrm{O}_{2}$ content $\left[\mathrm{C}(\mathrm{a}-\mathrm{v}) \mathrm{O}_{2}\right]$ and cardiac index (CI). In 13 additional cases, $\mathrm{C}(\mathrm{a}-\mathrm{v}) \mathrm{O}_{2}$, but not $\mathrm{Cl}$, was available.

Results: On day $1, \mathrm{VO}_{2}$ was markedly depressed $\left(67 \pm 28 \mathrm{ml} / \mathrm{min} / \mathrm{m}^{2}\right)$ despite a normal $\mathrm{Cl}\left(3.4 \pm 1.2 \mathrm{~L} / \mathrm{min} / \mathrm{m}^{2}\right)$. C(a-v) $\mathrm{O}_{2}$ was abnormally low in both patients either with $\left(2.0 \pm 1.0 \mathrm{ml} \mathrm{O}_{2} / 100 \mathrm{ml}\right.$ ) or without $\left(2.5 \pm 1.1 \mathrm{ml} \mathrm{O}_{2} / 100 \mathrm{ml}\right) \mathrm{Cl}$ (and $\mathrm{VO}_{2}$ ) monitoring. Clearance of the accumulated drug was associated with the resolution of lactic acidosis and a parallel increase in $\mathrm{VO}_{2}(P<0.001)$ and $\mathrm{C}(\mathrm{a}-\mathrm{V}) \mathrm{O}_{2}(P<0.05)$. Plasma lactate and $\mathrm{VO}_{2}$ were inversely correlated $\left(\mathrm{R}^{2} 0.43 ; P<0.001, \mathrm{n}\right.$ $=32$ ).

Conclusions: $\mathrm{VO}_{2}$ is abnormally low in patients with lactic acidosis due to biguanide intoxication. This finding is in line with the hypothesis of inhibited mitochondrial respiration and consequent hyperlactatemia.
\end{abstract}

\section{Introduction}

Metformin and phenformin are oral anti-diabetic drugs of the biguanide class. Metformin is the first-line drug of choice for the treatment of adults with type 2 diabetes [1]. It is the $10^{\text {th }}$ most frequently prescribed generic drug in the USA (>40 million prescriptions in 2008) and is currently used by almost one-third of diabetic patients in Italy $[2,3]$. Phenformin is no longer on sale in many countries, but is still available in Italy.

Lactic acidosis can develop in patients taking metformin or phenformin, especially when renal failure leads to drug accumulation [4-6]. According to the American Association of Poison Control Centers, metformin was implicated in 19 fatalities in the USA in 2007 [7]. Thirty cases of biguanide intoxication have been reported over the past two years to

\footnotetext{
*Correspondence: alessandro.protti@policlinico.mi.it

1 Fondazione IRCCS Ospedale Maggiore Policlinico, Mangiagalli e Regina Elena di Milano, Università degli Studi di Milano, Via F. Sforza 35, 20122 Milan, Italy
}

the Poison Control Centre of Pavia, Italy, resulting in 10 deaths (Dr Sarah Vecchio, unpublished data). The progressive increase in metformin use $(20 \%$ rise in prescriptions between 2006 and 2008 in the USA) may result in a parallel increase in the incidence of associated lactic acidosis $[2,8]$.

The pathogenesis of biguanide-associated lactic acidosis remains unclear, especially when it develops in the absence of other major risk factors such as hypoxia, tissue hypoperfusion, or liver failure (biguanide-induced lactic acidosis). Hyperlactatemia is classically attributed to an impaired lactate clearance, secondary to an exaggerated inhibition of hepatic gluconeogenesis [9] but may also depend on an increased lactate production by the liver [10] or the intestine [11].

Biguanide drugs mainly exert their therapeutic effect by impairing hepatocyte mitochondrial respiration $[12,13]$. Recent observations have suggested that metformin, similarly to phenformin, might also inhibit mitochondrial respi- 
ration in tissues other than the liver [14-16]. Mitochondria produce energy while consuming oxygen $\left(\mathrm{O}_{2}\right)$ and releasing carbon dioxide $\left(\mathrm{CO}_{2}\right)$ and heat. When $\mathrm{O}_{2}$ provision or utilization are compromised, cellular energy production can partly rely on the extra-mitochondrial anaerobic lactate generation, that is associated with metabolic acidosis. As mitochondrial respiration normally accounts for more than $90 \%$ of whole body $\mathrm{O}_{2}$ utilization and $\mathrm{CO}_{2}$ release, any defect in mitochondrial metabolism will decrease systemic $\mathrm{O}_{2}$ consumption and $\mathrm{CO}_{2}$ production.

We hypothesize that inhibition of mitochondrial respiration is responsible for the development of lactic acidosis during metformin or phenformin intoxication. If our hypothesis is correct, respiration should be abnormally low regardless of any change in systemic $\mathrm{O}_{2}$ delivery. The aim of this study is to investigate global $\mathrm{O}_{2}$ consumption (and $\mathrm{CO}_{2}$ production) in patients with lactic acidosis due to biguanide intoxication.

\section{Materials and methods}

We reviewed the data sheets of patients admitted to 12 intensive care units and 1 nephrology unit of 11 hospitals from January 2005 to June 2009, with a discharge diagnosis of lactic acidosis due to biguanide intoxication. Patients with a concomitant primary diagnosis of septic or cardiogenic shock or liver failure were excluded. Lactic acidosis was defined as $\mathrm{pH}$ less than 7.30 and plasma lactate more than $5 \mathrm{mM}$. Only patients with central or mixed venous $\mathrm{O}_{2}$ saturation monitoring were included.

We calculated the arterio-venous difference in $\mathrm{O}_{2}$ content $\left[\mathrm{C}(\mathrm{a}-\mathrm{v}) \mathrm{O}_{2}\right]$ as:

$$
\begin{aligned}
& \mathrm{CaO}_{2}-\mathrm{CvO}_{2}=\left(1.39 \times \mathrm{Hb} \times \mathrm{SaO}_{2}+0.003 \times \mathrm{PaO}_{2}\right) \\
& -\left(1.39 \times \mathrm{Hb} \times \mathrm{SvO}_{2}+0.003 \times \mathrm{PvO}_{2}\right),
\end{aligned}
$$

where $\mathrm{CaO}_{2}$ and $\mathrm{CvO}_{2}$ are arterial and venous blood $\mathrm{O}_{2}$ content, respectively, $\mathrm{Hb}$ is blood hemoglobin concentration, $\mathrm{SaO}_{2}$ is arterial $\mathrm{O}_{2}$ saturation, $\mathrm{SvO}_{2}$ is $\mathrm{O}_{2}$ saturation of blood taken from the superior vena cava or the pulmonary artery (collectively indicated as central venous blood) and $\mathrm{PaO}_{2}$ and $\mathrm{PvO}_{2}$ are the arterial and central venous $\mathrm{O}_{2}$ tensions.

Oxygen extraction index (OEI) was defined as:

$$
\left(\mathrm{CaO}_{2}-\mathrm{CvO}_{2}\right) / \mathrm{CaO}_{2}
$$

and expressed as a percentage. The veno-arterial difference in $\mathrm{CO}_{2}$ content $\left[\mathrm{C}(\mathrm{v}-\mathrm{a}) \mathrm{CO}_{2}\right]$ was calculated according to Douglas and colleagues [17]. In patients with cardiac index $(\mathrm{CI})$ monitoring, we calculated whole body $\mathrm{O}_{2}$ delivery $\left(\mathrm{DO}_{2}\right)$ as $\mathrm{CI} \times \mathrm{CaO}_{2}$ and $\mathrm{O}_{2}$ consumption $\left(\mathrm{VO}_{2}\right)$ as $\mathrm{CI} \times$ $\mathrm{C}(\mathrm{a}-\mathrm{v}) \mathrm{O}_{2}$, with $\mathrm{CI}$ computed as cardiac output divided by estimated body surface area. Carbon dioxide production $\left(\mathrm{VCO}_{2}\right)$ was calculated as $\mathrm{CI} \times \mathrm{C}(\mathrm{v}-\mathrm{a}) \mathrm{CO}_{2}$.

The severity of illness was initially expressed by the Simplified Acute Physiology Score (SAPS) II [18] and then monitored using the Sequential Organ Failure Assessment (SOFA) score [19]. The cardiovascular SOFA score was used to describe catecholamine requirements. Sedation was evaluated using the Richmond Agitation Sedation Scale (RASS) [20]. Heart rate, body temperature and need for mechanical ventilation were also recorded. Analysis was restricted to the first four days following admission, or until discharge or death if any of these occurred earlier.

The local Ethics Committee of the coordinating Centre (Fondazione IRCCS Ospedale Maggiore Policlinico, Mangiagalli e Regina Elena di Milano, Italy) was informed of the ongoing retrospective analysis and did not require any specific informed consent.

\section{Statistical analysis}

Results are presented as mean \pm standard deviation or median and interquartile range, based on data distribution (Kolmogorov-Smirnov test). The relation between serum metformin levels and other variables was assessed using linear regression analysis and expressed as $\mathrm{R}^{2}$. Severity of illness at admission of patients with or without CI monitoring was compared using the Student's $t$-test. The remainder of the analyses were performed on data averaged on a daily basis. Changes occurring over time were investigated using parametric or non-parametric one-way repeated-measures analysis of variance. Post-hoc comparisons were performed using Bonferroni or Dunn's test, considering day 1 as baseline. The relation between the arterio-venous difference in $\mathrm{O}_{2}$ content and the veno-arterial difference in $\mathrm{CO}_{2}$ content was calculated using linear regression. The relation between systemic $\mathrm{O}_{2}$ consumption and other variables was investigated using linear (arterial $\mathrm{pH}$ ) or non-linear (body temperature and plasma lactate) regression. The chisquared test was used to assess whether the proportion of patients requiring mechanical ventilation changed over time. Analysis was performed using Sigma Stat version 3.1.1 (Jandel Scientific Software; San Jose, CA, USA). A two-sided $P$ value less than 0.05 was considered as statistically significant.

\section{Results}

We identified 24 diabetic patients admitted to the intensive care $(n=22)$ or nephrology $(n=2)$ units with lactic acidosis attributed to either metformin $(n=23)$ or phenformin $(n=$ 1) intoxication (Table 1). Seventeen (71\%) were females and the mean age of all patients was $66 \pm 9$ years.

Lactic acidosis on hospital admission was always severe, with an arterial $\mathrm{pH}$ of $6.93 \pm 0.20$ and lactate of $18 \pm 6 \mathrm{mM}$. Blood glucose level was $118 \pm 78 \mathrm{mg} / \mathrm{dl}$, with severe hypoglycemia $(<40 \mathrm{mg} / \mathrm{dl})$ being present in 3 patients. Liver 
Table 1: Main characteristics of the study population

\begin{tabular}{|c|c|c|c|c|c|c|c|c|}
\hline Id & Intoxicant & $\begin{array}{c}\text { Serum } \\
\text { drug level } \\
(\mu \mathrm{g} / \mathrm{ml})\end{array}$ & $\begin{array}{c}\text { Creatinine } \\
\text { (mg/dl) }\end{array}$ & pH & $\begin{array}{c}\text { Lactate } \\
\text { (mM) }\end{array}$ & Monitoring & SAPS II & $\begin{array}{c}\text { ICU } \\
\text { outcome }\end{array}$ \\
\hline 1 & Metformin & 70 & 6.4 & 7.21 & 22 & $\mathrm{Cl} \mathrm{S} \overline{\mathrm{VO}}{ }_{2}$ & 58 & $S$ \\
\hline 2 & Metformin & 63 & 12.4 & 6.95 & 33 & $\mathrm{Cl} \mathrm{S} \overline{\mathrm{VO}}{ }_{2}$ & 53 & $S$ \\
\hline 3 & Metformin & NA & 10.8 & 6.76 & 21 & $\mathrm{Cl} ; \mathrm{S} \overline{\mathrm{VO}}{ }_{2}$ & 61 & $S$ \\
\hline 4 & Metformin & NA & 15.2 & 7.06 & 18 & $\mathrm{Cl} ; \mathrm{S} \overline{\mathrm{V}} \mathrm{O}_{2}$ & 51 & $S$ \\
\hline 5 & Metformin & NA & 9.0 & 6.63 & 21 & $\mathrm{Cl} ; \mathrm{S} \overline{\mathrm{V}} \mathrm{O}_{2}$ & 55 & $S$ \\
\hline 6 & Metformin & NA & 10.3 & 6.82 & 21 & $\mathrm{Cl} ; \mathrm{ScvO}_{2}$ & 87 & $S$ \\
\hline 7 & Metformin & NA & 10.8 & 6.70 & 24 & $\mathrm{Cl} ; \mathrm{ScvO}_{2}$ & 74 & $S$ \\
\hline 8 & Metformin & 61 & 1.9 & 7.27 & 10 & $\mathrm{Cl} ; \mathrm{S} \overline{\mathrm{V}} \mathrm{O}_{2}$ & 83 & NS \\
\hline 9 & Metformin & NA & 13.2 & 6.79 & 21 & $\mathrm{Cl} ; \mathrm{ScvO}_{2}$ & 63 & $S$ \\
\hline 10 & Metformin & NA & 4.7 & 7.13 & 19 & $\mathrm{Cl} ; \mathrm{ScvO}_{2}$ & 66 & $S$ \\
\hline 11 & Metformin & 53 & 4.5 & $<6.80$ & 16 & $\mathrm{Cl} \mathrm{S} \overline{\mathrm{VO}}{ }_{2}$ & 87 & NS \\
\hline 12 & Metformin & 65 & 8.4 & 6.76 & 22 & $\mathrm{ScvO}_{2}$ & 43 & $S$ \\
\hline 13 & Phenformin & $480^{\S}$ & 9.5 & 6.91 & 13 & $\mathrm{ScvO}_{2}$ & 59 & $S$ \\
\hline 14 & Metformin & 100 & 5.8 & 7.26 & 10 & $\mathrm{ScvO}_{2}$ & 58 & $S$ \\
\hline 15 & Metformin & 63 & 4.2 & 6.89 & 18 & $\mathrm{ScvO}_{2}$ & 53 & NS \\
\hline 16 & Metformin & NA & 13.0 & 6.93 & 17 & $\mathrm{ScvO}_{2}$ & 67 & $S$ \\
\hline 17 & Metformin & $19^{+}$ & 9.9 & 6.62 & 19 & $\mathrm{ScvO}_{2}$ & 62 & $S$ \\
\hline 18 & Metformin & NA & 6.1 & $<6.80$ & 24 & $\mathrm{ScvO}_{2}$ & 70 & NS \\
\hline 19 & Metformin & 100 & 7.6 & 6.87 & 16 & $\mathrm{ScvO}_{2}$ & 45 & $S$ \\
\hline 20 & Metformin & $25^{\dagger}$ & 9.3 & 6.81 & 15 & $\mathrm{ScvO}_{2}$ & 44 & $\mathrm{~S}$ \\
\hline $21^{*}$ & Metformin & 70 & 4.8 & 7.22 & 11 & $\mathrm{ScvO}_{2}$ & 66 & $S$ \\
\hline $22^{*}$ & Metformin & 44 & 10.0 & 6.93 & 14 & $\mathrm{ScvO}_{2}$ & 55 & S \\
\hline 23 & Metformin & NA & 13.8 & 7.21 & 6 & $\mathrm{ScvO}_{2}$ & 39 & $S$ \\
\hline 24 & Metformin & NA & 7.1 & 6.93 & 17 & $\mathrm{ScvO}_{2}$ & 65 & NS \\
\hline
\end{tabular}

The first available serum drug concentration ( ${ }^{\S}$ phenformin in $\mathrm{ng} / \mathrm{ml} ;+$ blood sample obtained with ongoing renal replacement therapy), creatinine level, arterial blood $\mathrm{pH}$ and plasma lactate level, available data $\left(\mathrm{Cl}\right.$, cardiac index; $\mathrm{ScvO}_{2}$, central venous oxymetry; $\mathrm{S} \overline{\mathrm{vO}}{ }_{2}$, mixed venous oxymetry), severity of the disease (expressed as Simplified Acute Physiology Score (SAPS) II score) and outcome (S = survivor; NS = non survivor) are reported. Target values in patients on metformin or phenformin are less than $4 \mu \mathrm{g} / \mathrm{ml}$ and less than $140 \mathrm{ng} / \mathrm{ml}$, respectively. ICU, intensive care unit; NA, not available; * patients admitted to the Nephrology Unit.

function tests were usually normal, with alanine aminotransferase $66 \pm 78 \mathrm{IU} / \mathrm{L}$, total bilirubin $0.4 \pm 0.2 \mathrm{mg} / \mathrm{dl}$, albumin $33 \pm 6 \mathrm{~g} / \mathrm{L}$, and prothrombin time (expressed as international normalized ratio) $1.2 \pm 0.3$ (excluding two patients on warfarin). Left ventricular ejection fraction, investigated in seven patients by echocardiography, was always normal $(\geq 50 \%)$.

Intoxication was always accidental and associated with renal failure (creatinine $8.7 \pm 3.5 \mathrm{mg} / \mathrm{dl}$, urea $171 \pm 70 \mathrm{mg} /$ $\mathrm{dl}$ and oligo-anuria) and continued drug intake. Factors potentially implicated in the development of renal failure 
Table 2: Temporal changes observed in 11 biguanide-intoxicated patients with cardiac index and central venous oxygen saturation monitoring

\begin{tabular}{|c|c|c|c|c|c|c|}
\hline & $\mathbf{n}$ & Day 1 & Day 2 & Day 3 & Day 4 & $\mathbf{P}$ \\
\hline $\mathrm{pH}$ & 11 & $\begin{array}{c}7.03 \\
(6.92-7.15)\end{array}$ & $\begin{array}{c}7.35 \\
(7.25-7.40)\end{array}$ & $\begin{array}{c}7.44 \\
(7.35-7.46)^{*}\end{array}$ & $\begin{array}{c}7.46 \\
(7.44-7.47)^{*}\end{array}$ & $<0.001$ \\
\hline Lactate $(\mathrm{mM})$ & 11 & $17(14-20)$ & $5(2-15)$ & $2(2-3)^{*}$ & $1(1-3)^{*}$ & $<0.001$ \\
\hline $\mathrm{VO}_{2}\left(\mathrm{ml} / \mathrm{min} / \mathrm{m}^{2}\right)$ & 9 & $67 \pm 28$ & $99 \pm 30^{*}$ & $116 \pm 41^{*}$ & $129 \pm 42^{*}$ & $<0.001$ \\
\hline $\mathrm{DO}_{2}\left(\mathrm{ml} / \mathrm{min} / \mathrm{m}^{2}\right)$ & 9 & $443 \pm 167$ & $572 \pm 152$ & $491 \pm 95$ & $430 \pm 116$ & $<0.01$ \\
\hline $\mathrm{Cl}\left(\mathrm{L} / \mathrm{min} / \mathrm{m}^{2}\right)$ & 9 & $3.4 \pm 1.2$ & $4.4 \pm 1.3$ & $3.9 \pm 0.8$ & $3.4 \pm 1.2$ & 0.08 \\
\hline $\begin{array}{c}\mathrm{C}(\mathrm{a}-\mathrm{v}) \mathrm{O}_{2} \\
\left(\mathrm{ml} \mathrm{O} \mathrm{O}_{2} / 100 \mathrm{ml}\right)\end{array}$ & 10 & $2.0 \pm 1.0$ & $2.4 \pm 0.8$ & $2.9 \pm 0.8^{*}$ & $3.8 \pm 1.4^{*}$ & $<0.001$ \\
\hline $\mathrm{SvO}_{2}(\%)$ & 10 & $83 \pm 8$ & $80 \pm 6$ & $75 \pm 5^{*}$ & $70 \pm 8^{*}$ & $<0.001$ \\
\hline OEI (\%) & 10 & $13(11-19)$ & $16(13-21)$ & $23(21-25)^{*}$ & $31(23-34)^{*}$ & $<0.001$ \\
\hline $\begin{array}{c}\mathrm{C}(\mathrm{v}-\mathrm{a}) \mathrm{CO}_{2} \\
(\mathrm{ml} \mathrm{CO} / 100 \mathrm{ml})\end{array}$ & 7 & $2.2 \pm 0.8$ & $2.2 \pm 0.8$ & $3.9 \pm 1.9$ & $4.7 \pm 1.2^{*}$ & $<0.05$ \\
\hline RASS & 11 & $-4(-5--2)$ & $-4(-4--1)$ & $-2(-4-0)$ & $-1(-3-0)$ & 0.06 \\
\hline On MV (\%) & 11 & 91 & 100 & 67 & 67 & 0.12 \\
\hline $\mathrm{HR}$ & 11 & $103 \pm 20$ & $104 \pm 8$ & $99 \pm 16$ & $97 \pm 21$ & 0.74 \\
\hline SOFA & 11 & $12 \pm 3$ & $10 \pm 1 *$ & $9 \pm 2^{*}$ & $10 \pm 2^{*}$ & $<0.001$ \\
\hline $\begin{array}{l}\text { Catecholamine } \\
\text { use (SOFA sub } \\
\text { score) }\end{array}$ & 11 & $4(4-4)$ & $4(4-4)$ & $4(4-4)$ & $3(2-3)^{*}$ & $<0.001$ \\
\hline $\mathrm{BT}\left({ }^{\circ} \mathrm{C}\right)$ & 10 & $34.5 \pm 2.2$ & $36.6 \pm 0.6^{*}$ & $36.8 \pm 0.4^{*}$ & $36.7 \pm 0.5^{*}$ & $<0.001$ \\
\hline
\end{tabular}

Results of repeated-measures analysis of variance and chi-squared test are reported in the right column. Data significantly different from day 1 on post-hoc comparison are indicated as ${ }^{*} . \mathrm{n}$ is the number of patients with each specific variable monitored on day 1.BT, body temperature; $\mathrm{C}(\mathrm{a}-\mathrm{v}) \mathrm{O}_{2}$, arterio-venous difference in oxygen content; $\mathrm{C}(\mathrm{v}-\mathrm{a}) \mathrm{CO}_{2}$, veno-arterial difference in carbon dioxide content; $\mathrm{Cl}$, cardiac index; $\mathrm{DO}_{2}$, systemic oxygen delivery; $\mathrm{HR}$, heart rate; $\mathrm{MV}$, mechanical ventilation; $\mathrm{OEI}$, oxygen extraction index; RASS, Richmond Agitation Sedation Score; SOFA, Sequential Organ Failure Assessment; $\mathrm{SvO}_{2}$, central venous oxygen saturation; $\mathrm{VO}_{2}$, systemic oxygen consumption.

were dehydration (a history of several days' vomiting and/ or diarrhea was reported in $75 \%$ of the cases), urinary tract infection $(29 \%)$ and chronic renal dysfunction $(21 \%)$.

Whenever measured, serum drug concentration on day 1 was always well above safe limits (metformin $61 \pm 25$ vs. $<4 \mu \mathrm{g} / \mathrm{ml}, \mathrm{n}=12$; phenformin 480 vs. $<140 \mathrm{ng} / \mathrm{ml}, \mathrm{n}=1$ ). Metformin levels, measured at different time points in 10 patients, were positively correlated with those of creatinine $\left(\mathrm{R}^{2}=0.34 ; P<0.001, \mathrm{n}=29\right)$ and lactate $\left(\mathrm{R}^{2}=0.49 ; P<\right.$ $0.001, \mathrm{n}=29)$ and inversely correlated with arterial $\mathrm{pH}\left(\mathrm{R}^{2}\right.$ $=0.68 ; P<0.001, \mathrm{n}=29$ ).

Treatment included the use of mechanical ventilation ( $\mathrm{n}=$ 16), catecholamines $(n=21)$ and renal replacement therapy $(\mathrm{n}=21)$. The first day SAPS II score was $61 \pm 13$, corresponding to an expected mortality of approximately $70 \%$. Observed mortality was $21 \%$.
Central venous $\mathrm{O}_{2}$ saturation was monitored through a central venous $(n=17)$ or pulmonary artery $(n=7)$ catheter. Blood gases were always measured at $37^{\circ} \mathrm{C}$. In 11 patients, $\mathrm{CI}$ was also measured, using the PiCCO system $(\mathrm{n}=2)$, transesophageal Doppler ultrasonography $(\mathrm{n}=2)$ or pulmonary artery catheter thermodilution $(\mathrm{n}=7)$. Patients with $\mathrm{CI}$ monitoring had a higher SAPS II (67 \pm 14 vs. $56 \pm 10 ; P<$ $0.05)$ and SOFA $(12 \pm 3$ vs. $9 \pm 2 ; P<0.05)$ scores on admission.

Main results are reported in Table 2 and Figures 1 and 2. Systemic $\mathrm{O}_{2}$ consumption, monitored in 11 patients, was abnormally low on day 1 and normalized within the next 48 to 72 hours $(P<0.001)$, paralleled by resolution of lactic acidosis $(P<0.001)$. As systemic $\mathrm{O}_{2}$ delivery did not significantly change compared with day 1 , variations in whole body $\mathrm{O}_{2}$ consumption were reflected in equal changes in 

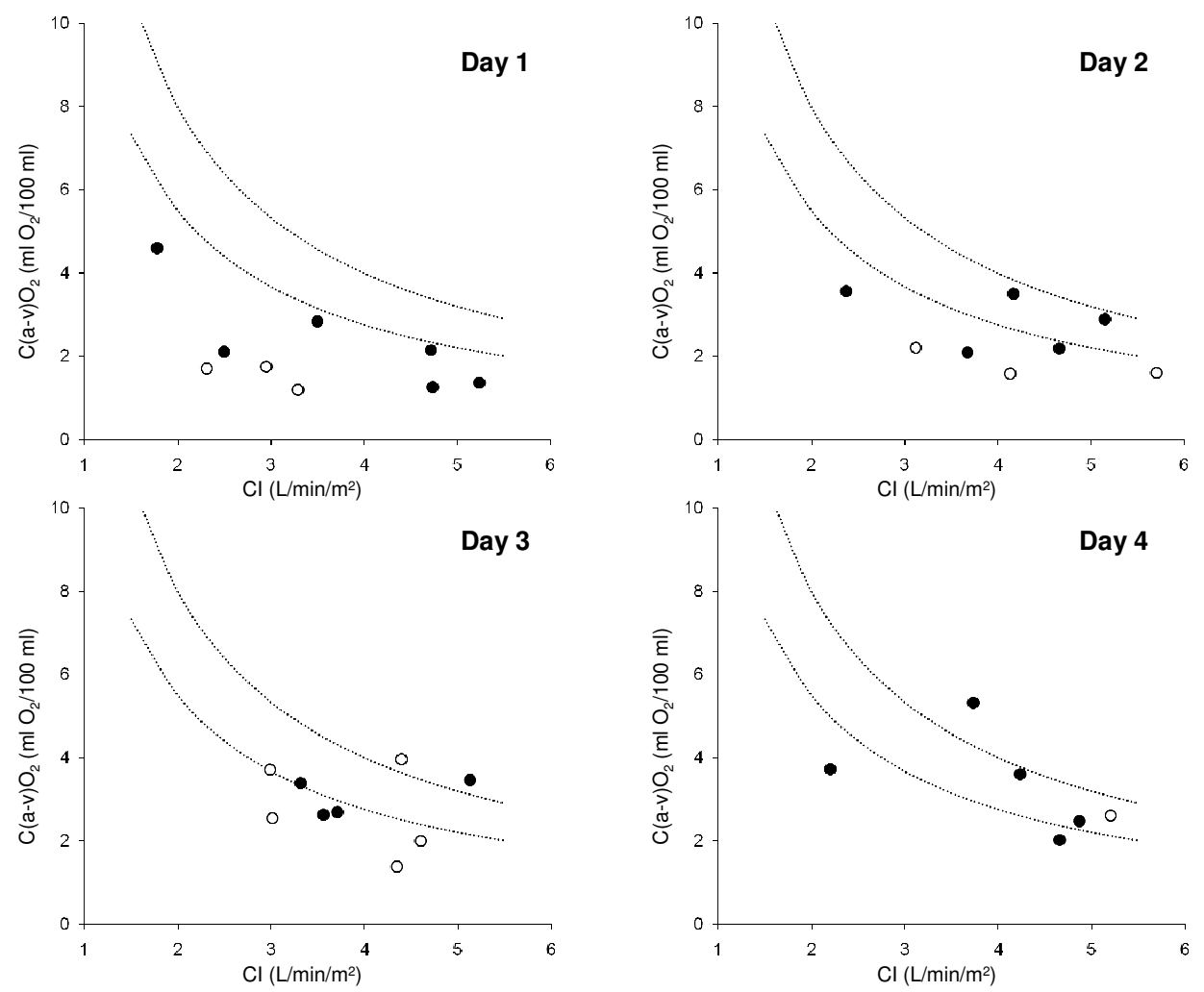

Figure 1 Relation between cardiac index and arterio-venous difference in oxygen content in biguanide-intoxicated patients. Cardiac index $(\mathrm{Cl})$ and arterio-venous difference in oxygen content $\left[\mathrm{C}(\mathrm{a}-\mathrm{v}) \mathrm{O}_{2}\right]$ recorded during the first 4 days of admission from 11 biguanide-intoxicated patients. Each circle refers to individual data averaged on a daily basis. The arterio-venous difference in oxygen content was computed from either mixed (black circles) or central (white circles) venous oxygen saturation. Dotted lines refer to the lower and upper limits of normal systemic oxygen consumption (110 to $160 \mathrm{ml} / \mathrm{min} / \mathrm{m}^{2}$ ). Circles that are located under the lower dotted line indicate an arterio-venous difference in oxygen content (oxygen extraction) lower than expected if systemic oxygen consumption is normal.

arterio-venous difference in $\mathrm{O}_{2}$ content and $\mathrm{O}_{2}$ extraction index and opposite changes in central venous $\mathrm{O}_{2}$ saturation $\left(P<0.001\right.$ for all). The difference in veno-arterial $\mathrm{CO}_{2}$ content was abnormally low on day 1 and progressively returned to normal $(P<0.05)$. Whole body $\mathrm{CO}_{2}$ production showed a similar, although not significant, trend, rising from $93 \pm 24$ (on day 1 ) to $115 \pm 13 \mathrm{ml} / \mathrm{min} / \mathrm{m}^{2}$ (on day $4 ; \mathrm{n}$ $=4$ ). The arterio-venous difference in $\mathrm{O}_{2}$ content was positively associated with the veno-arterial difference in $\mathrm{CO}_{2}$ content $\left(\mathrm{R}^{2}=0.42 ; P=0.001, \mathrm{n}=22\right)$. Systemic $\mathrm{O}_{2}$ consumption was positively associated with arterial $\mathrm{pH}\left(\mathrm{R}^{2}=\right.$ $0.37 ; P<0.001, \mathrm{n}=32)$ and body temperature $\left(\mathrm{R}^{2}=0.38 ; P\right.$ $<0.001, \mathrm{n}=30$ ) and inversely correlated with plasma lactate $\left(\mathrm{R}^{2}=0.43 ; P<0.001, \mathrm{n}=32\right)$.

Major findings remained valid when the analysis was restricted to the 7 patients monitored with a pulmonary artery catheter. From day 1 to 4 , lactate levels decreased from 16 (13 to 19$)$ to 1 ( 1 to 2$) \mathrm{mM}(P<0.01)$. Global $\mathrm{O}_{2}$ consumption increased ( $81 \pm 21$ vs. $129 \pm 47 \mathrm{ml} / \mathrm{min} / \mathrm{m}_{2} ; P$ $=0.01)$ despite no change in systemic $\mathrm{O}_{2}$ delivery $(482 \pm$ 180 vs. $441 \pm 139 \mathrm{ml} / \mathrm{min} / \mathrm{m} 2 ; P=0.10)$. The arteriovenous difference in $\mathrm{O}_{2}$ content $(2.3 \pm 1.2$ vs. $3.9 \pm 1.1 \mathrm{ml}$ $\left.\mathrm{O}_{2} / 100 \mathrm{ml} ; P=0.001\right)$ and the $\mathrm{O}_{2}$ extraction index $(17 \pm 7$ vs. $30 \pm 6 \% ; P<0.001)$ augmented and the mixed venous $\mathrm{O}_{2}$ saturation accordingly decreased $(81 \pm 9$ vs. $69 \pm 6 \% ; P$ $=0.001)$. The difference in veno-arterial $\mathrm{CO}_{2}$ content increased from $2.4 \pm 0.7$ to $4.6 \pm 1.5 \mathrm{ml} \mathrm{CO}_{2} / 100 \mathrm{ml}(P<$ 0.05). Systemic $\mathrm{O}_{2}$ consumption inversely correlated with plasma lactate $\left(\mathrm{R}^{2}=0.30 ; P=0.01, \mathrm{n}=21\right)$.

In patients without $\mathrm{CI}$ monitoring, initial values and later changes in the other variables of interest closely resembled those observed in monitored patients (Table 3).

Twelve patients had one or more simultaneous determinations of serum metformin levels and arterio-venous differ- 


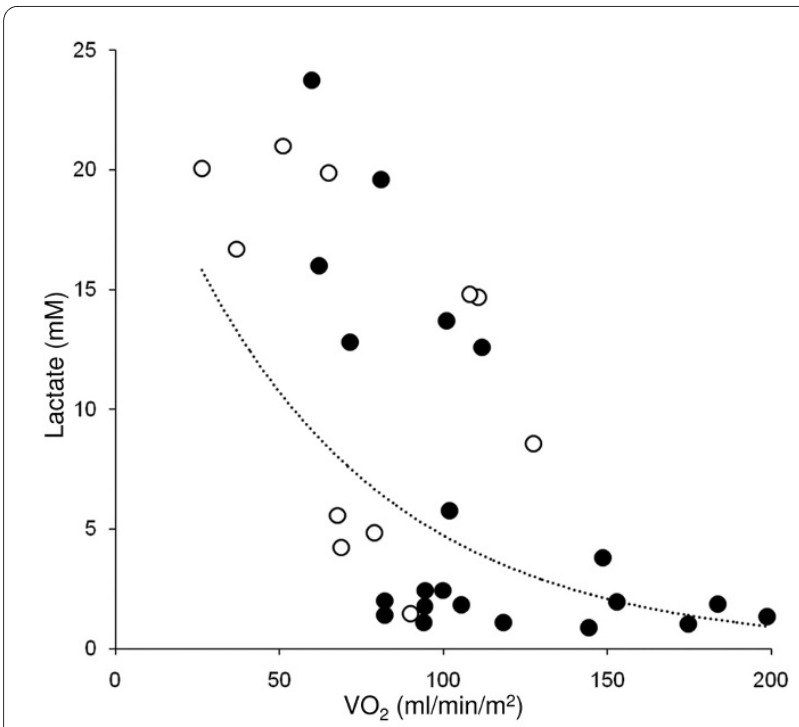

Figure 2 Relation between systemic oxygen consumption and lactatemia in biguanide-intoxicated patients. Systemic oxygen consumption $\left(\mathrm{VO}_{2}\right)$, computed from either mixed (black circles) or central (white circles) venous oxygen saturation, inversely correlated with plasma lactate $\left(R^{2}=0.43 ; P<0.001 ; n=32\right)$. ence in $\mathrm{O}_{2}$ content; an inverse correlation was noted between these variables $\left(\mathrm{R}^{2}=0.20 ; P<0.05, \mathrm{n}=22\right)$.

\section{Discussion}

The present study demonstrates that whole body $\mathrm{O}_{2}$ consumption (and $\mathrm{CO}_{2}$ production) are abnormally low during biguanide-induced lactic acidosis and return to normal on recovery from drug intoxication.

Metformin is a safe drug when correctly prescribed [21]. Lactic acidosis can develop in cases of drug accumulation but is usually attributed to other concomitant precipitating factors. However, some reports suggest that metformin accumulation may cause lactic acidosis even in the absence of other obvious confounding variables [22]. According to discharge diagnosis, patients included in this present study suffered from lactic acidosis (better defined as hyperlactatemia with metabolic acidosis) mainly attributed to (documented or suspected) metformin or phenformin intoxication. None of the patients had any sign of acute liver or cardiac failure. Acute renal failure was invariably present at hospital admission, but could have hardly represented the sole cause of such a dramatic rise in blood lactate levels. Septic shock was never reported as the primary diag-

Table 3: Temporal changes observed in 13 biguanide-intoxicated patients with central venous oxygen saturation (but not cardiac index) monitoring

\begin{tabular}{|c|c|c|c|c|c|c|}
\hline & $\mathbf{n}$ & Day 1 & Day 2 & Day 3 & Day 4 & $\mathbf{P}$ \\
\hline $\mathrm{pH}$ & 13 & $7.14 \pm 0.17$ & $7.36 \pm 0.10^{*}$ & $7.45 \pm 0.09^{*}$ & $7.43 \pm 0.06^{*}$ & $<0.001$ \\
\hline Lactate (mM) & 13 & $12 \pm 6$ & $5 \pm 8^{*}$ & $2 \pm 1^{*}$ & $2 \pm 1^{*}$ & $<0.001$ \\
\hline $\begin{array}{c}\mathrm{C}(\mathrm{a}-\mathrm{v}) \mathrm{O}_{2} \\
\left(\mathrm{ml} \mathrm{O}_{2} / 100 \mathrm{ml}\right)\end{array}$ & 12 & $2.5 \pm 1.1$ & $3.1 \pm 1.0$ & $3.4 \pm 0.8$ & $4.2 \pm 1.2^{*}$ & $<0.05$ \\
\hline $\mathrm{SvO}_{2}(\%)$ & 12 & $79 \pm 10$ & $75 \pm 10$ & $73 \pm 6^{*}$ & $66 \pm 7^{*}$ & 0.01 \\
\hline OEI (\%) & 12 & $20 \pm 10$ & $24 \pm 10$ & $25 \pm 7$ & $33 \pm 7^{*}$ & 0.01 \\
\hline $\begin{array}{c}\mathrm{C}(\mathrm{v}-\mathrm{a}) \mathrm{CO}_{2} \\
(\mathrm{ml} \mathrm{CO} / 100 \mathrm{ml})\end{array}$ & 8 & $2.4 \pm 1.6$ & $2.8 \pm 1.2$ & $3.6 \pm 0.9$ & $5.5 \pm 1.9$ & 0.16 \\
\hline RASS & 13 & $-1(-4-0)$ & $0(-3-0)$ & $0(-1-0)$ & $-1(-3-0)$ & 0.05 \\
\hline On MV (\%) & 13 & 31 & 42 & 27 & 38 & 0.89 \\
\hline $\mathrm{HR}$ & 12 & $87 \pm 17$ & $88 \pm 15$ & $91 \pm 14$ & $88 \pm 8$ & 0.10 \\
\hline SOFA & 13 & $9 \pm 2$ & $8 \pm 3$ & $6 \pm 3^{*}$ & $7 \pm 3^{*}$ & $<0.001$ \\
\hline $\begin{array}{l}\text { Catecholamine } \\
\text { use (SOFA sub } \\
\text { score) }\end{array}$ & 13 & $3 \pm 2$ & $3 \pm 2$ & $2 \pm 2^{*}$ & $2 \pm 2^{*}$ & $<0.01$ \\
\hline $\mathrm{BT}\left({ }^{\circ} \mathrm{C}\right)$ & 10 & $\begin{array}{c}35.8 \\
(35.0-36.3)\end{array}$ & $\begin{array}{c}36.8 \\
(36.4-37.3)\end{array}$ & $\begin{array}{c}37.0 \\
(36.7-37.5)^{*}\end{array}$ & $\begin{array}{c}36.9 \\
(36.6-37.4)\end{array}$ & $<0.05$ \\
\hline
\end{tabular}

Results of repeated-measures analysis of variance and chi-squared test are reported in the right column. Data significantly different from day 1 on post-hoc comparison are indicated as * $\mathrm{n}$ is the number of patients with each specific variable monitored on day 1. $\mathrm{BT}$, body temperature; $\mathrm{C}(\mathrm{a}-\mathrm{v}) \mathrm{O}_{2}$, arterio-venous difference in oxygen content; $\mathrm{C}(\mathrm{v}-\mathrm{a}) \mathrm{CO}_{2}$, veno-arterial difference in carbon dioxide content: $\mathrm{HR}$, heart rate; MV, mechanical ventilation; OEl, oxygen extraction index; RASS, Richmond Agitation Sedation Score; SOFA, Sequential Organ Failure Assessment; $\mathrm{SvO}_{2}$, central venous oxygen saturation. 
nosis. Sepsis may still have acted as a precipitating factor (gastroenteritis, urinary tract infection) but could not explain our present initial findings. Indeed, systemic $\mathrm{O}_{2}$ consumption is usually normal or even increased in critically ill septic patients, at least in the early phase $[23,24]$.

The most common cause of lactic acidosis in critically ill patients is probably cellular hypoxia. When $\mathrm{O}_{2}$ delivery acutely decreases due to low cardiac output, anemia or hypoxemia, tissue $\mathrm{O}_{2}$ extraction rises in an attempt to preserve aerobic mitochondrial respiration. The arterio-venous difference in $\mathrm{O}_{2}$ content, that is the ratio between whole body $\mathrm{O}_{2}$ consumption and cardiac output, increases and central venous $\mathrm{O}_{2}$ saturation decreases. Oxygen consumption only starts to diminish when $\mathrm{O}_{2}$ delivery falls below a critical value; the blood lactate concentration then abruptly increases, indicating the development of anaerobic metabolism [25]. The veno-arterial difference in $\mathrm{CO}_{2}$ content, that depends on the ratio between $\mathrm{CO}_{2}$ production and cardiac output, may rise as well, mainly as a consequence of a reduced cardiac output.

Lactic acidosis can also develop under aerobic conditions, when $\mathrm{O}_{2}$ utilization is prevented by mitochondrial dysfunction, glycolysis is overly stimulated or lactate clearance is impaired [26-28]. Growing evidence, mainly derived from cell and animal studies, suggest that metformin and phenformin can actually interfere with mitochondrial respiration in a dose-dependent manner $[10,12-$ 14]. By interfering with mitochondrial respiration in the liver, they decrease gluconeogenesis (and lactate clearance) and may potentially increase glucose consumption (and lactate production) $[10,12,13]$. Although the effect on organs and tissues other than the liver is less clear, metformin can still diminish mitochondrial respiration and increase glycolysis (and lactate release) in the skeletal muscle [14]. Whether the drug can decrease global $\mathrm{O}_{2}$ consumption in either animals or humans remains poorly investigated and unclear [29-31]. Based on these observations, we hypothesize that during metformin or phenformin accumulation, the inhibition of mitochondrial respiration is so strong that the production of lactate (by the liver and, probably, other tissues) increases above the residual capacity of the body to clear it, leading to the development of lactic acidosis.

Our results support this hypothesis. In fact, systemic $\mathrm{O}_{2}$ consumption, measured in 11 patients, was markedly depressed in the early phase, when lactic acidosis was more dramatic, despite a normal, or even increased, $\mathrm{O}_{2}$ delivery. This finding may be cautiously extended to 13 additional patients in whom systemic $\mathrm{O}_{2}$ consumption could not be computed, from initial recording of very low values of arterio-venous difference in $\mathrm{O}_{2}$ content, diminished peripheral $\mathrm{O}_{2}$ extraction and increased central venous $\mathrm{O}_{2}$ saturation. Similar changes occur after exposure to cyanide, a well- known inhibitor of mitochondrial respiration [32]. Even if acidosis was more likely the result of a diminished mitochondrial respiration, it might have also contributed to further decrease the systemic energy expenditure and $\mathrm{O}_{2}$ consumption [33]. However, the basal systemic $\mathrm{O}_{2}$ consumption of 15 critically ill, mechanically ventilated patients enrolled in a previous trial led by our group, with an arterial $\mathrm{pH}$ below 7.20 , was $123 \pm 65 \mathrm{ml} / \mathrm{min} / \mathrm{m}^{2}$ [34].

Alterations in $\mathrm{O}_{2}$ consumption were apparently paralleled by changes in $\mathrm{CO}_{2}$ production. Direct measurement of systemic $\mathrm{CO}_{2}$ production using the reverse Fick equation requires calculation of the whole blood veno-arterial difference in $\mathrm{CO}_{2}$ content. This primarily consists of physically dissolved $\mathrm{CO}_{2}$, bicarbonate ions and carbamino compounds. As whole blood $\mathrm{CO}_{2}$ content is not routinely measured, we computed it using an algorithm that includes the $\mathrm{CO}_{2}$ tension, $\mathrm{pH}$, hemoglobin concentration and $\mathrm{O}_{2}$ saturation [17]. Similar to arterio-venous difference in $\mathrm{O}_{2}$ content, the initially low difference between venous and arterial $\mathrm{CO}_{2}$ content is suggestive of diminished $\mathrm{CO}_{2}$ production.

Previous studies have demonstrated that severity of illness, use of sedatives and catecholamines, heart rate, body temperature and mechanical ventilation can all affect resting energy expenditure $[35,36]$. Overall, systemic $\mathrm{O}_{2}$ consumption, arterio-venous difference in $\mathrm{O}_{2}$ content and venoarterial difference in $\mathrm{CO}_{2}$ content reached their nadir when severity of illness and use of catecholamines were at their highest values. Patient awakening occurred slowly, well after the normalization of $\mathrm{O}_{2}$ consumption and related variables. Heart rate and the need for mechanical ventilation did not significantly change over time. A body temperature on hospital admission averaging 34 to $35^{\circ} \mathrm{C}$ cannot, in isolation, explain the observed 40 to $60 \%$ reduction in systemic $\mathrm{O}_{2}$ consumption, because $\mathrm{O}_{2}$ consumption should diminish by approximately 5 to $6 \%$ for every $1{ }^{\circ} \mathrm{C}$ fall in temperature [37,38]. Moreover, the systemic $\mathrm{O}_{2}$ consumption of 25 critically ill patients, with a body temperature between 34 to $35^{\circ} \mathrm{C}$, was $136 \pm 40 \mathrm{ml} / \mathrm{min} / \mathrm{m}^{2}$ [34]. None of the patients included in the present study had any obvious reason to be hypothermic on hospital admission: they usually arrived from home, were awake and with pale, cold extremities. Hypothermia was more likely the consequence of the biguanide-induced decrease in metabolic rate. Even if abnormally low body temperature may impact upon the interpretation of the blood gas analyses performed at $37^{\circ} \mathrm{C}$, temperature correction is unnecessary to compute the arterio-venous differences in $\mathrm{O}_{2}$ and $\mathrm{CO}_{2}$ content [39].

Some of the limitations of this present study deserve a comment. First, we did not include any control group, because of the peculiar characteristics of the study population. However, every single patient with biguanide intoxica- 
tion acted as an internal control, with individual recordings of global $\mathrm{O}_{2}$ consumption (and $\mathrm{CO}_{2}$ production) being significantly lower on day 1 , relative to the following days. Second, we used the central venous $\mathrm{O}_{2}$ saturation to compute global $\mathrm{O}_{2}$ consumption of patients equipped with a cardiac output monitoring but not a pulmonary artery catheter. As catecholamine use did not change over time in these subjects, changes in central venous $\mathrm{O}_{2}$ saturation (and derived variables) likely reflected those in mixed venous $\mathrm{O}_{2}$ saturation. Moreover, when the analysis was restricted to the 7 patients equipped with a pulmonary artery catheter, the major findings of the study remained valid. Third, the respiratory quotient - the ratio between the difference in $\mathrm{CO}_{2}$ and $\mathrm{O}_{2}$ content of simultaneously drawn arterial and venous blood samples - sometimes exceeded one, an unexpected finding, at least at steady state. Possible explanations include the fact that, in our study population, blood gas analysis were not performed at steady state and blood $\mathrm{CO}_{2}$ content was estimated rather than directly measured. We cannot, however, definitely exclude the occurrence of any error in blood sampling, gas analysis or data reporting.

\section{Conclusions}

Metformin and phenformin intoxication is characterized by severe lactic acidosis and abnormally low systemic oxygen consumption despite normal or even increased systemic oxygen delivery. These findings are consistent with the hypothesis that biguanide drugs cause lactic acidosis by inhibiting mitochondrial respiration, without any clear evidence of cellular hypoxia. Cause and effect still needs to be conclusively demonstrated.

\section{Key messages}

- The progressive increase in metformin use may result in a parallel increase in the incidence of associated lactic acidosis.

- The pathogenesis of biguanide-associated lactic acidosis remains unclear, especially when it develops in the absence of other major risk factors.

- Biguanide intoxication is characterized by severe lactic acidosis and abnormally low systemic $\mathrm{O}_{2}$ consumption, despite normal or even increased global oxygen delivery.

- Resolution of drug intoxication is paralleled by correction of lactic acidosis and normalization of systemic $\mathrm{O}_{2}$ consumption.

- These findings are in line with the hypothesis that lactic acidosis develops during metformin or phenformin intoxication because of inhibition of mitochondrial respiration.

\section{Abbreviations}

$\mathrm{C}(\mathrm{a}-\mathrm{v}) \mathrm{O}_{2}$ : arterio-venous difference in oxygen content; $\mathrm{C}(\mathrm{v}-\mathrm{a}) \mathrm{CO}_{2}$ : veno-arterial difference in carbon dioxide content; $\mathrm{CaO}_{2}$ : arterial blood oxygen content; $\mathrm{CVO}_{2}$ : venous blood oxygen content; $\mathrm{Cl}$ : cardiac index; $\mathrm{CO}_{2}$ : carbon dioxide; $\mathrm{DO}_{2}$ : systemic oxygen delivery; $\mathrm{O}_{2}$ : oxygen; OEl: oxygen extraction index; $\mathrm{PaO}_{2}$ : arterial venous oxygen tensions; $\mathrm{PvO}_{2}$ : central venous oxygen tensions; RASS: Richmond Agitation Sedation Score; SAPS II: Simplified Acute Physiology Score II; $\mathrm{SaO}_{2}$ : arterial oxygen saturation; SOFA: Sequential Organ Failure Assessment; $\mathrm{SVO}_{2}$ : central venous oxygen saturation; $\mathrm{VCO}_{2}$ : systemic carbon dioxide production; $\mathrm{VO}_{2}$ : systemic oxygen consumption.

\section{Competing interests}

The authors declare that they have no competing interests.

\section{Authors' contributions}

AP conceived the study, participated in its design and coordination, performed the statistical analysis and drafted the manuscript. RR, PT, and SV participated in study design and data collection. MS, AR, and GF participated in data collection, interpretation of data and helped to draft the manuscript. AR participated in study design and data collection. GM participated in data collection and helped with statistical analysis. LG participated in study design, interpretation of data and helped to draft the manuscript. All the authors read and approved the final manuscript.

\section{Acknowledgements}

Preliminary results were presented at the $21^{\text {st }}$ Annual Meeting of the European Society of Intensive Care Medicine (ESICM), held in Lisbon (Portugal) in 2008. List of participating centers (all in Italy, unless otherwise stated): Centro Nazionale di Informazione Tossicologica, Fondazione IRCCS Salvatore Maugeri, Pavia; Fondazione IRCCS - Ospedale Maggiore Policlinico, Mangiagalli e Regina Elena, Milano; Ospedale di Faenza, Ravenna; Ospedale di Manerbio, Brescia; Ospedale di Sondrio; Ospedale di Vimercate; Ospedale Maggiore di Novara; Ospedale Maggiore Niguarda, Milano; Ospedale San Gerardo Nuovo dei Tintori, Monza; Ospedale San Paolo, Milano; University College Hospital, London, UK; University Hospital Zurich, Switzerland.

\section{Author Details}

1Fondazione IRCCS Ospedale Maggiore Policlinico, Mangiagalli e Regina Elena di Milano, Università degli Studi di Milano, Via F. Sforza 35, 20122 Milan, Italy, 2Ospedale San Gerardo Nuovo dei Tintori, Università di Milano-Bicocca, Piazza dell'Ateneo Nuovo 1, 20126, Milan, Italy, ${ }^{3}$ Centro Nazionale di Informazione Tossicologica, Fondazione IRCCS Salvatore Maugeri, Via Maugeri 10, 27100 Pavia, Italy, 4Bloomsbury Institute of Intensive Care Medicine, University College London, 5 University Street, London WC1E 6JF, UK, 5 University Hospital Zurich, Rämistrasse 100, 8091 Zürich, Switzerland, 'Ospedale Niguarda Ca' Granda, Piazza Ospedale Maggiore 3, 20162 Milan, Italy and 7Ospedale San Paolo, Università degli Studi di Milano, Via A. Di Rudiní 8, 20142 Milan, Italy

Received: 27 October 2009 Revisions Requested: 23 December 2009 Revised: 9 January 2010 Accepted: 19 February 2010

Published: 19 February 2010

\section{References}

1. American Diabetes Association: Standards of medical care in diabetes-2008. Diabetes Care 2008, 31 Suppl 1:S12-S54.

2. 2008 Top 200 generic drugs by total prescriptions [http:// drugtopics.modernmedicine.com/drugtopics/data/articlestandard// drugtopics/222009/599844/article.pdf]

3. L'uso dei Farmaci in Italia. Rapporto Nazionale anno 2007 [http:// www.agenziafarmaco.it/allegati/rapporto osmed 2007.pdf]

4. Lalau JD, Race JM: Lactic acidosis in metformin-treated patients. Prognostic value of arterial lactate levels and plasma metformin concentrations. Drug Saf 1999, 20:377-384.

5. Peters N, Jay N, Barraud D, Cravoisy A, Nace L, Bollaert PE, Gibot S: Metformin-associated lactic acidosis in an intensive care unit. Crit Care 2008, 12:R149.

6. Seidowsky A, Nseir S, Houdret N, Fourrier F: Metformin-associated lactic acidosis: a prognostic and therapeutic study. Crit Care Med 2009, $37: 2191-2196$ 
7. Bronstein AC, Spyker DA, Cantilena LR Jr, Green JL, Rumack BH, Heard SE, American Association of Poison Control Centers: 2007 Annual Report of the American Association of Poison Control Centers' National Poison Data System (NPDS): 25th Annual Report. Clin Toxicol (Phila) 2008, 46:927-1057.

8. Personne M: Alarming increase of the number of metformin intoxications. Ten times doubled number of inquiries to the Swedish Poison Information Center since 2000. Lakartidningen 2009, 106:994

9. Wang DS, Kusuhara H, Kato Y, Jonker JW, Schinkel AH, Sugiyama Y Involvement of organic cation transporter 1 in the lactic acidosis caused by metformin. Mol Pharmacol 2003, 63:844-848.

10. Dykens JA, Jamieson J, Marroquin L, Nadanaciva S, Billis PA, Will Y: Biguanide-induced mitochondrial dysfunction yields increased lactate production and cytotoxicity of aerobically-poised HepG2 cells and human hepatocytes in vitro. Toxicol App/ Pharmacol 2008, 233:203-210.

11. Bailey CJ, Wilcock C, Scarpello JH: Metformin and the intestine. Diabetologia 2008, 51:1552-1553.

12. El-Mir MY, Nogueira V, Fontaine E, Avéret N, Rigoulet $M$, Leverve X: Dimethylbiguanide inhibits cell respiration via an indirect effect targeted on the respiratory chain complex I. J Biol Chem 2000, 275:223-228.

13. Owen MR, Doran E, Halestrap AP: Evidence that metformin exerts its anti-diabetic effects through inhibition of complex 1 of the mitochondrial respiratory chain. Biochem J 2000, 348:607-614.

14. Brunmair B, Staniek K, Gras F, Scharf N, Althaym A, Clara R, Roden M, Gnaiger E, Nohl H, Waldhäusl W, Fürnsinn C: Thiazolidinediones, like metformin, inhibit respiratory complex I: a common mechanism contributing to their antidiabetic actions? Diabetes 2004, 53:1052-1059

15. Zmijewski JW, Lorne E, Zhao X, Tsuruta Y, Sha Y, Liu G, Siegal GP, Abraham $\mathrm{E}$ : Mitochondrial respiratory complex I regulates neutrophil activation and severity of lung injury. Am J Respir Crit Care Med 2008, 178:168-179.

16. Hinke SA, Martens GA, Cai Y, Finsi J, Heimberg H, Pipeleers D, Casteele M Van de: Methyl succinate antagonises biguanide-induced AMPKactivation and death of pancreatic beta-cells through restoration of mitochondrial electron transfer. Br J Pharmacol 2007, 150:1031-1043.

17. Douglas AR, Jones NL, Reed JW: Calculation of whole blood $\mathrm{CO}_{2}$ content. J Appl Physiol 1988, 65:473-477.

18. Le Gall JR, Lemeshow S, Saulnier F: A new Simplified Acute Physiology Score (SAPS II) based on a European/North American multicenter study. JAMA 1993, 270:2957-2963.

19. Vincent JL, de Mendonça A, Cantraine F, Moreno R, Takala J, Suter PM, Sprung CL, Colardyn F, Blecher S: Use of the SOFA score to assess the incidence of organ dysfunction/failure in intensive care units: results of a multicenter, prospective study. Working group on "sepsis-related problems" of the European Society of Intensive Care Medicine. Crit Care Med 1998, 26:1793-1800.

20. Sessler CN, Gosnell MS, Grap MJ, Brophy GM, O'Neal PV, Keane KA, Tesoro EP, Elswick RK: The Richmond Agitation-Sedation Scale: validity and reliability in adult intensive care unit patients. Am J Respir Crit Care Med 2002, 166:1338-1344.

21. Salpeter S, Greyber E, Pasternak G, Salpeter E: Risk of fatal and nonfatal lactic acidosis with metformin use in type 2 diabetes mellitus. Cochrane Database Syst Rev 2006, 1:CD002967.

22. Runge S, Mayerle J, Warnke C, Robinson D, Roser M, Felix SB, Friesecke S: Metformin-associated lactic acidosis in patients with renal impairment solely due to drug accumulation? Diabetes Obes Metab 2008, 10:91-93.

23. Kreymann G, Grosser S, Buggisch P, Gottschall C, Matthaei S, Greten H: Oxygen consumption and resting metabolic rate in sepsis, sepsis syndrome, and septic shock. Crit Care Med 1993, 21:1012-1019.

24. Moriyama S, Okamoto K, Tabira Y, Kikuta K, Kukita I, Hamaguchi M, Kitamura N: Evaluation of oxygen consumption and resting energy expenditure in critically ill patients with systemic inflammatory response syndrome. Crit Care Med 1999, 27:2133-2136.

25. Vincent $\mathrm{J}$, De Backer D: Oxygen transport-the oxygen delivery controversy. Intensive Care Med 2004, 30:1990-1996.

26. James JH, Luchette FA, McCarter FD, Fischer JE: Lactate is an unreliable indicator of tissue hypoxia in injury or sepsis. Lancet 1999, 354:505-508.

27. Fink MP: Cytopathic hypoxia. Is oxygen use impaired in sepsis as a result of an acquired intrinsic derangement in cellular respiration? Crit Care Clin 2002, 18:165-175
28. Levy B, Gibot S, Franck P, Cravoisy A, Bollaert PE: Relation between muscle $\mathrm{Na}+\mathrm{K}+$ ATPase activity and raised lactate concentrations in septic shock: a prospective study. Lancet 2005, 365:871-875.

29. Ramadan W, Petitjean M, Loos N, Geloen A, Vardon G, Delanaud S, Gros F, Dewasmes G: Effect of high-fat diet and metformin treatment on ventilation and sleep apnea in non-obese rats. Respir Physiol Neurobiol 2006, 150:52-65.

30. Johnson ST, Robert C, Bell GJ, Bell RC, Lewanczuk RZ, Boulé NG: Acute effect of metformin on exercise capacity in active males. Diabetes Obes Metab 2008, 10:747-754.

31. Braun B, Eze P, Stephens BR, Hagobian TA, Sharoff CG, Chipkin SR, Goldstein B: Impact of metformin on peak aerobic capacity. Appl Physiol Nutr Metab 2008, 33:61-67.

32. Peddy SB, Rigby MR, Shaffner DH: Acute cyanide poisoning. Pediatr Crit Care Med 2006, 7:79-82.

33. Hillered L, Ernster L, Siesjö BK: Influence of in vitro lactic acidosis and hypercapnia on respiratory activity of isolated rat brain mitochondria. J Cereb Blood Flow Metab 1984, 4:430-437.

34. Gattinoni L, Brazzi L, Pelosi P, Latini R, Tognoni G, Pesenti A, Fumagalli R: A trial of goal-oriented hemodynamic therapy in critically ill patients. $\mathrm{SvO}_{2}$ Collaborative Group. N Engl J Med 1995, 333:1025-1032.

35. Frankenfield DC, Omert LA, Badellino MM, Wiles CE, Bagley SM, Goodarz $\mathrm{S}$, Siegel $\mathrm{JH}$ : Correlation between measured energy expenditure and clinically obtained variables in trauma and sepsis patients. JPEN J Parenter Enteral Nutr 1994, 18:398-403.

36. Faisy C, Guerot E, Diehl JL, Labrousse J, Fagon JY: Assessment of resting energy expenditure in mechanically ventilated patients. Am J Clin Nutr 2003, 78:241-249.

37. Harris EA, Seelye ER, Squire AW: Oxygen consumption during cardiopulmonary bypass with moderate hypothermia in man. $\mathrm{Br} J$ Anaesth 1971, 43:1113-1120.

38. Bacher A, Illievich UM, Fitzgerald R, Ihra G, Spiss CK: Changes in oxygenation variables during progressive hypothermia in anesthetized patients. J Neurosurg Anesthesiol 1997, 9:205-210.

39. Shapiro BA, Peruzzi WT: Blood gas analysis. In Critical Care 3rd edition. Edited by: Civetta JM, Taylor RW, Kirby RR. Philadelphia: Lippincott-Raven; 1997:921-939.

doi: $10.1186 /$ cc8885

Cite this article as: Protti et al., Oxygen consumption is depressed in patients with lactic acidosis due to biguanide intoxication Critical Care 2010, 14:R22 